\title{
Maritime English Teachers in Indonesia
}

\author{
L Puspitasari $^{1}$, P N F L Batu ${ }^{2}$, S Kusumaningrum ${ }^{3}$, R S Wulandari ${ }^{4}$ \\ \{lila.sujatmoko@gmai1.com1,nancy.lumbanbatu@gmail.com ${ }^{2}$,sari.kusuma0601@gmail.com ${ }^{3}$,shota_ku8 \\ $2 @$ yahoo.com $\left.{ }^{4}\right\}$ \\ ${ }^{1,2,3,4}$ STIP (Sekolah Tinggi Ilmu Pelayaran) Jakarta, Indonesia
}

\begin{abstract}
English has always been essential in Maritime, especially when reached to safety. As a global industry, Maritime sector needs English as the medium to communicate, to create understanding among multinational organization and crew.To countries that have English as their 2nd language, or even as a foreign language, it is still a challenge. Therefore, Maritime English teacher or instructor is a key figure to develop seafarer capabilities. Maritime English Teachers in Indonesia should not only have some English language skills but also specialized training for career purposes, especially in Maritime English teaching because the goal of Maritime English for each college is to cultivate students to have good English communication skills that used on board ship. Based on this standard, Maritime English teachers are expected to be familiar with the related maritime knowledge, so it is possible to encourage the students to use the English for their communication on board ship. This study is intended to identify and to profile the typical maritime English teachers in Indonesia. The study involves 5 Maritime Colleges across Indonesia by distributing questionnaires to collect the data, either through emails or on-site visit. The data is then tabulated to complete the profiles. The idea is to share the findings of the study to the policymaker of Maritime Education and Training Regulator.
\end{abstract}

Keywords: Maritime English Teacher; Standard Qualification; ESP

\section{Introduction}

A teacher is a person who helps others to acquire knowledge, competences, and values. Teachers use their knowledge of subject matter, experiences, and technology to facilitate the students in advancing their learning and creativity. Teachers also responsible to design, develop, and evaluate the learning process. The duties may extend beyond formal teaching, like accompany students learn outside of the classroom on field trips, supervise study halls, and serves as supervisors for extracurricular activities. In some education systems, teachers may have responsibility for student discipline.

Based on this case, professionalism seems important to reach the requirement of being a good teacher as per government regulation in Indonesia. As for the teacher's workload covers planning, execution, and control learning process; evaluation of learning outcomes; mentoring and training; research, community service, and other supporting activities.

The number of universities in Indonesia reaches 4.350 universities with various specifications. Maritime College is one of them that is intended for learners who want to become a seafarer. In this institution, there are three majors such as Nautical, Engineering and Port and Shipping Management which provide a lot of knowledge related to maritime studies. A teacher has a big role to produce qualified sailors due to many important things that need to 
know by the learner here, one of them is about communication on board. When critical decisions have to be made quickly to protect safety and security on board, good communication between all involved in the maritime chain is essential. In the world of international transport and shipping, the chosen international standard language for achieving effective communication on board and between ships to shore is the English language. It is not only because of an international requirement for certification of seafarers but also a key element in ensuring safe, efficient and profitable ship operation. International Maritime Organization (IMO)[1] has formally agreed to use Maritime English (ME) as the language of maritime industry. Maritime English as an ESP is likely a combination of language and professional knowledge, so a qualified Maritime English Teacher (MET) must master the General English and professional Maritime (communication on board) English, because the goal Maritime English is to cultivate the students having good professional English communication skills that used on board ship.

Maritime English Teachers in Indonesia should not only have some English language skills but also specialized training for career purposes, especially in Maritime English teaching. The innovation of the teaching approach should be applied in the classroom. The problem for student is that their motivation for their acquiring knowledge is low. Part of students does not have enough courage to use English openly, especially when they are doing communication with

Foreigners. For this case, Indonesian teachers are required not only to be able to transfer the knowledge of ME but also how to encourage students to use English for their communication conversation and let students conscious about the serious and useful future purpose of Maritime English which relates to their opportunities of gaining a better life and enhanced the job achievement. There should be any standardized of being qualified Maritime English teachers from IMO consider the ability in both transferring knowledge and motivating the students.

Based on the description above, the following questions will be discussed in this study: 1 ) What is the typology of MET in Indonesia?, 2) Are there professional standards for being MET in Indonesia?, and 3) Are all the MET in Indonesia qualified as per the standard?

\section{Literature review}

\subsection{Maritime English - Definition, and Requirements}

Maritime English, being an ESP, is one of professional specialized technical English that should be effective for communication between ship and shore, between crew members and even passenger in order to ensure the safety at sea [2]. Since English was officially adopted by International Maritime Organization (IMO) as the language of the sea in 1995, Teaching of English to mariners has increased due to the introduction of the International Safety Management Code and the development of the SMCP (Standard Marine Communication Phrase). The practice of deck and engineering crew training in Maritime English is carried out in close connection with the development of national and international standards [3]. Maritime English is an operational language that specializes vocabulary is considerable but grammar is limited taking in the communication onboard.

\subsection{Profiling Maritime English Teachers}

English for Specific Purposes covers the specialized language and vocabularies that needed for variety of careers or occupations so teacher should not only have General English 
language skill but also specialized language for career purposes such as Maritime English Teaching. Some institutions have demands from IMO that a qualified of MET as follows:

a. A qualified English teacher should receive a better education in language because an English teacher must be not only skilled at the using of language but also familiar with the traditions in English speaking countries.

b. A qualified MET should be familiar with the Maritime subjects and their vocabularies covering all maritime subjects, such as the international regulations, navigational technology, aids to navigations, cargo handling, vessel maneuvering, weather reports, standard maritime communication phrases, ship logbook and so on.

c. A qualified MET should be familiar with some maritime operations. The practicality of ME requires the better ability of case analyzing, but most English- trained maritime English teacher lack the experience on board which makes them not understand the textbook content thoroughly.

In the other hand, becoming a MET requires neither internationally established nor certified competences [4]. According to their project METs are:

Career specialist that means they are graduates or qualified teachers, knowing what they are really teaching as long as it is relevant to the needs of ME learners, enjoys a comparatively good standing in the workplace and even cooperation with technical subject colleagues. It considers that they may be qualified to teach ME.

English language and literature graduates who are lovers of English, but do not necessarily understand applied linguistics especially for English for Specific Purpose. They are not trained of Maritime English knowledge so they usually prefer to teach general English. For this case, a number of ME institutions employ these teachers without asking too much about what exactly they teach in their classes.

Former Seafarers who are technical experts have a primacy experience of being seafarers but not skilled in teaching language or in teaching methodology overall.

Native English Speaking Person who are temporarily hired as teachers. The expectation is motivating students to listen and speak in English. However, this group seldom brings with them teaching skills or maritime knowledge.

According to the information above, it will be wise if there is any clear regulation to decide which kind of teacher fit to handle the class of Maritime English, so there is no misunderstanding to classify the MET of each institution.

\subsection{Government Standard for Teachers}

Being a teacher is something worth when the professionalism defines the quality of teacher it selves. The quality is reflected by having skills, competency, minimum level of education as required in the regulation, and certification of expertise. In Indonesia, teachers should meet the following standard as stated in the Government regulation no. 44, 2015 article26:

a. Teachers have healthy qualifications physically and spiritually. It is a basic term that can be approved by a certificate of health from hospital.

b. Lecturers are required to have an academic qualification at least as a master graduate or applied magister in accordance with the field.

c. Lecturers of professional programs are required to have an academic qualification at least as a master graduate or applied magister in accordance to the field and have at least 2 (two) years of experience.

Teachers are considered the most important impact factor on the quality of student achievement. Based on a large scale on factor influencing learning outcome of student, Hattie 
[5] suggests that the quality of teachers has a larger impact on the learning of students than the quality of the curriculum, the teaching methods, the school building or the role of parents. The needs in the quality of teachers are based on the challenges that government face to the education system. The challenge for Indonesia in Maritime scope is to fill the needs of seafarers who are estimated still less up to 18.000 each year. For this case, the Maritime Education and Training in Indonesia are required to produce qualified seafarers to compete in the global era. It is clear that a teacher has a big role of this situation moreover many shipowners are complain about the Indonesian sailors poor in English.

\section{Method}

\subsection{Data Collection}

a. Interview

For the purposes of this research, an in-depth interview were used. It is to identify personal's opinion regarding particular research problems. The success of the interview depends on the process of interaction and communication in the interview. The content of the questions is also a factor affecting the result of the interview.

b. Questionnaire

As far as data collection tools are concerned, the conduction of the research involved the use of a questionnaire. Some certain questions are prepared to identify the answers of the research questions. In this paper the questionnaire is distributed extensively through email or websites as well as maritime colleges or even personal contact.

c. Documentation

The method is to find data on things or variables in the form of notes, transcripts, books, newspaper, websites, and so on. This method is used for obtaining maritime English list data and their qualification of each college.

\subsection{Analysis of Data}

The data analysis work includes three steps as follows:

a. Preparation

Check the completeness of data, the contents of data instruments, and data entry.

a. Tabulation

Included into this activity is a tabulation of data, data deduction, data analysis for hypothesis testing, or purpose of conclusion [6].

b. Application of data in accordance with the research approach and this paper runs the qualitative approach.

\subsection{Population and Sample}

A sample is part of population of the study. There are more than 30 Maritime Colleges in Indonesia that can be used as a population in this study. To enrich the credible information collected, the purposive sample is the number of maritime English teachers in 9 colleges in Indonesia. 


\subsection{Time and Place}

The study conducted in 9 maritime colleges in Indonesia surely with the permission of the authorities. They are Sekolah Tinggi Ilmu Pelayaran (STIP), Jakarta; Akademi Maritim Nasional Jakarta; Akademi Maritim Djadajat; Akademi Maritim Cirebon; Politeknik Ilmu Pelayaran (PIP), Surabaya; PIP, Makasar; Akademi Maritim Indonesia (AMI) Medan; Akademi Maritim Belawan; and Akademi Maritim Maluku.

\section{Result and Discussion}

\subsection{The Typology of Maritime English Teacher in Indonesia}

Based on the tabulation table from questionnaire and interview, there are two types of Maritime English teachers in Maritime Universities across Indonesia. The typology may be found as follows:

a. English Teachers with General English Background

This group included some English teachers who are very familiar with the foreign language. During their college life, they have been trained the language systematically so they are good in transferring the knowledge about language such as grammar, pronunciation, word order. They are enjoyed with teaching general English, especially in Maritime Institutions that the students do not have that much attention to English language learning/acquisition. But they lack Maritime knowledge which covers navigations, ship handling, international regulation, ship's structure, cargo handling, emergency situation, etc. Therefore, most of these teachers often meet difficulties in explaining the ESP's vocabularies and sentences in the classroom. This automatically makes it difficult for them to collaborate the maritime fields with English teaching. In the other hands, they need to receive Maritime knowledge training in order to facilitate them in delivering material as well as an ESP purpose.

b. English Teacher with MaritimeBackground

This kind of Maritime English teachers is very familiar with the maritime subject. They graduated maritime college and were engaged to be an officer on deck or an engineer in the engine room afterward. They have studied the maritime knowledge and have one-year sea project onboard ship experience. It is obvious if they are better to help the students in understanding English materials related to maritime context, i.e. English Maritime reading comprehension. But they have never received regular English language or take a course for English school teachers so they are not good in language field such as grammar, pronunciation, and word order that make them difficult to explain in detail about what they want to say and discuss.

When we are talking about the standard/ideal English teachers, this group is absolutely not recommended. This is usually done by some institutions because there are not enough qualified English teachers to deal with former seafarer as their students.

\subsection{Professional Standard of Maritime English in Indonesia}

According to Government regulation no. 44, 2015 article 26 which stated about the standard of being professional teachers are required to have an academic qualification at least as a master graduate or applied magister in accordance to the field and have at least 2 (two) years of experience, we found the data from 6 Maritime Universities in Indonesia as follows: 


\begin{tabular}{|c|c|c|c|c|c|c|c|}
\hline \multirow[b]{2}{*}{ No } & \multirow[b]{2}{*}{ College } & \multirow{2}{*}{$\begin{array}{c}\text { Total } \\
\text { Teachers }\end{array}$} & \multirow{2}{*}{$\begin{array}{l}\text { Edscational } \\
\text { Background }\end{array}$} & \multicolumn{2}{|c|}{ Major } & \multicolumn{2}{|c|}{$\begin{array}{c}\text { Teaching } \\
\text { Exporience }\end{array}$} \\
\hline & & & & Eng. & Nax: & $\begin{array}{l}<2 \\
\text { yean }\end{array}$ & $\begin{array}{l}>2 \\
\text { years }\end{array}$ \\
\hline 1 & 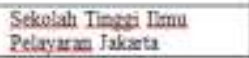 & 8 & 7 Mastets & 8 & - & - & 8 \\
\hline 2 & $\begin{array}{l}\text { Akademi Maritim } \\
\text { Nasiocal Saloarta }\end{array}$ & 2 & 2 Bachelors & 1 & 1 & * & 2 \\
\hline 3 & $\begin{array}{l}\text { Akadeni Alaritim } \\
\text { Djadaiat. }\end{array}$ & 2 & $\begin{array}{l}1 \text { Master } \\
1 \text { Bochelor }\end{array}$ & 1 & 1 & - & 2 \\
\hline 4 & Aksdemi Maritim Ctrebob & 2 & $\begin{array}{l}\text { 1 Master } \\
1 \text { Bachelor }\end{array}$ & 1 & 1 & - & 2 \\
\hline 5 & $\begin{array}{l}\text { Politeinnik Iims Peizyaran } \\
\text { Surabayz }\end{array}$ & 2 & 2 Masters & 2 & - & * & 2 \\
\hline 0 & $\begin{array}{l}\text { Politeknik timu Pelayaras } \\
\text { Melasar }\end{array}$ & 3 & 3 Mastets & 3 & - & - & 3 \\
\hline 7 & Akademi Maritim Modm & 3 & 3 Masters & 2 & 1 & $*$ & 3 \\
\hline 8 & $\begin{array}{l}\text { Alademi Maritim } \\
\text { Belarea }\end{array}$ & 2 & $\begin{array}{l}\text { 1. Master } \\
1 \text { Bacheior }\end{array}$ & 2 & - & : & 2 \\
\hline 9 & Akademi Maritim Mafulon & 3 & $\begin{array}{l}\text { 2 Massets } \\
1 \text { Bachelot }\end{array}$ & 2 & 1 & - & 3 \\
\hline
\end{tabular}

Table 1: Maritime English Lecturers' data at each University

\section{Conclusion}

There are two kinds of Maritime English teachers in most Maritime Institution in Indonesia, such as English teachers with the General English background and English teachers with the Maritime background. For Maritime English teachers who have Maritime background are not good in general English, lack of knowledge about systematical English studies, and considered poor in ESP's teaching method. In the other hands, most Maritime English teachers with the General English Background are not really familiar in maritime English and maritime subjects.

It is suggested to participate the training of general maritime short course or sent on board ship for several months to get a chance having communication with the seafarer and crews for the purpose of increasing their knowledge about maritime industries while for the maritime background teachers are advised to take English study/course to improve their ability in comprehending English language entirely.

\section{References}

[1] International Maritime Organization, "The Standard of Training, Certification and Watchkeeping of Seafarers," 1995.

[2] V. Karastateva, "Teaching Maritime English at a technical university," BETA-IATEFL Publications, 2011. .

[3] N. Demydenko, "International standards of Maritime English as a means to improve safety at sea," J. Mar. Technol. Environ., vol. 1, pp. 91-94, 2010.

[4] C. Cole, B. Pritchard, and P. Trenkner, "Maritime English instruction-ensuring instructors' competence," Ibérica, Rev. la Asoc. Eur. Lenguas para Fines Específicos, vol. 14, pp. 123-147, 2007.

[5] J. Hattie, Visible Learning, Asynthesis of over 800 meta-analyses relating to achievement. London: Routledge, 2009. 